Hansen.) Detailed diagnoses, line illustrations of conidia and chlamydospores, and some good photographs in colour of monoconidial cultures of the wild type of each species, variety or form are given.

\section{Chromatography of Phycocyanin}

E. C. WAssink and H. W. J. Rageth have reported on a paper chromatographic analysis of the blue solution obtained by the acid hydrolysis of the photosynthetically active chromoprotein, phycocyanin, of the blue-green algæ Oscillatoria (Proc. Koninkl. Nederlandse Akad, van Wetensch., Ser. C., $L V, 4,462$; 1952). The analysis yielded sixteen amino-compounds of which thirteen were known amino-acids and three were unknown substances, one of these last being present in relatively large amount. Arginine was absent; but otherwise the assay of the Oscillatoria phycocyanin did not reveal important differences from the bulk proteins of the green algæ Chlorella vulgaris (with chloroplast proteins) or from horse hæmoglobin.

\section{Blundell's School Science Society}

THE seventh issue of the Blundell's School Science Society magazine again shows the remarkably fine work being done at boarding schools in Britain in the training of young scientists. One article, for example, describes some studies of the biology of ivy-leaved duckweed (Lemna trisulca) by a senior boy, M. J. Corrigan. Among the questions he investigated were methods of encouraging growth, the effect of temperature and the role of auxin on growth, the growth of the plant under different wave-lengths and intensities of light, as well as the reasons which cause Lemna trisulca to sink to the bottom of a canal in winter and to cause its fronds to float just below the water-surface at other times. Corrigan's article is supported by two others by boys who, like him, have been awarded school prizes for their original work. The magazine also describes the many meetings held by the Science Society during 1951-52 and the records compiled by individual members and subcommittees of the Society in and around Tiverton. In addition there is an admirable account by two boys of a recent visit to an old but recently resuscitated iron-works at Dunsford.

\section{Fourteenth International Congress of Zoology, Copenhagen}

The Fourteenth International Congress of Zoology will be held in Copenhagen during August 5-12. It has been decided to have a fairly large number of sections, so that comparatively specialized fields can be discussed, and a provisional list of sections (with the name of each organizer) has been arranged as follows : nomenclature (Dr. H. Lemche), invertebrate palæozoology (Prof. Chr. Poulsen), vertebrate palæozoology (Dr. E. Nielsen), quaternary zoology (I). M. Degerbøl), zoogeography (Prof. R. Spärck), speciation (Dr. F. Salomonsen), genetics of populations (Dr. H. Lemche), cytology (Dr. H. Holter), sub-microscopical structure of animals (Prof. H. V. Brøndsted), animal regeneration (Prof. H. V. Brøndsted), morphogenesis (Prof. H. V. Brøndsted), animal psychology and othology (Dr. H. Poulsen), comparative physiology (Prof. P. Brandt Rehberg), parasitology (Prof. M. Christiansen), nematology (Dr. P. Bovien), terrestrial ecology (Dr. Ellinor Bro Larsen), marine ecology (Dr. G. Thorson), entomology (Dr. S. L. Tuxen), vertebrate systematics (Dr. M. Degerbøl) and invertebrate systematics (Dr. P. L. Kramp). Four general meetings have been planned at which lectures lasting about an hour will be given on topics of general interest, followed by discussion. At the section meetings a specialist will be invited to give a lecture lasting about forty minutes, which will cover a central problem of the section concerned; added to this, members may read short papers, not more than twenty minutes in duration, and also give brief demonstrations of animals, slides, films, etc. The official languages of the Congress will be English, French and German. All who wish to contribute to the proceedings or reserve hotel accommodation should communicate with the secretariat before April 15; the last date for membership registration is June 1. All communications should be addressed to the secretariat of the Congress at Krystalgade 27, Copenhagen $K$.

Immediately before the Congress a colloquium, organized by Mr. Francis Hemming, will be held by the International Commission on Zoological Nomenclature, officially representing the International Union of Biological Sciences. During the Congress a colloquium will be held on "Zoogeographical Problems of the Deep-Sea Fauna", organized by Prof. R. Spärck.

\section{Rumford Bicentenary Celebrations in the United States}

THE bicentenary of the birth of Benjamin Thompson, Count Rumford, on March 26, 1753, will be celebrated in the United States at Boston, during March 26-28, by the American Academy of Arts and Sciences. The social functions in the celebrations will be a dinner on March 26, at which Sanborn $\mathrm{C}$. Brown, of the Massachusetts Institute of Technology, will give an account of his researches into the life of Rumford, and on March 27 a ceremony will be held at which Rumford Medals of the Academy will be presented to Profs. E. Fermi, W. E. Lamb, jun., and L. Onsager. In addition, during the morning and afternoon of March 27 and the morning of March 28, respectively, the following three symposia will be held, at which the speakers will be as shown : recent developments in thermodynamics (Prof. P. W. Bridgman, Harvard; Sir Alfred Egerton, London; Prof. L. Onsager, Yale; and Prof. F. E. Simon, Oxford) ; recent developments in atomic spectroscopy (Dr. M. Deutsch, Massachusetts Institute; Prof. W. E. Lamb, jun., Stanford ; Dr. E. M. Purcell, Harvard; and Prof. I. I. Rabi, Columbia); and recent developments in nuclear physics (Prof. E. Fermi, Chicago ; Prof. J. R. Oppenheimer, Institute for Advanced Research, Princeton; Prof. M. Siegbahn, Nobel Institute, Stockholm ; and Prof. V. F. Weisskopf, Massachusetts Institute).

\section{The Night Sky in March}

New moon occurs on March 15d. 1lh. 05m., U.T., and full moon on March $30 \mathrm{~d} .12 \mathrm{~h}$. 55m. The following conjunctions with the moon take place: March 4d. 23h., Saturn $8^{\circ}$ N.; March 17d. 20h., Venus $2^{\circ}$ N. March 17d. 20h., Mars 5 ${ }^{\circ}$ S. ; March 19d. 06h., Jupiter $6^{\circ} \mathrm{S}$. In addition to these conjunctions with the moon, Venus is in conjunction with Mars on March 17d. 23h., Venus being $7^{\circ}$ N. Mercury sets at $19 \mathrm{~h} .20 \mathrm{~m}$. at the beginning of the month, but draws closer to the sun and is in inferior conjunction on March 18, after which it becomes a morning star, being, however, too close to the sun for observation during the remainder of the month. Venus, an evening star, sets at $21 \mathrm{~h}$. $55 \mathrm{~m} ., 2 \mathrm{~h} .45 \mathrm{~m}$. and 